DOI https://doi.org/10.30525/978-9934-26-000-1-5

\title{
ТРЕНДИ КОНТЕНТ-ІНДУСТРІЇ ЄВРОПИ В УМОВАХ ВИКЛИКІВ ПАНДЕМІЇ
}

\author{
Ковпак В. А. \\ професор кафедри теорії комунікачії, реклами та зв 'язків \\ із громадськістю факультету журналістики \\ Запорізький національний університет \\ м. Запоріжжя, Украӥна
}

Ювілейний, десятий Kyiv media week Global Marathon відбувся цьогоріч у форматі міжнародного онлайн марафону, де аналізувалися тренди й перспективи аудіовізуальної індустрії України та світу, шукали антикризові рішення для сталого розвитку медіаринку. Ексклюзивні аналітичні огляди, актуальні дослідження, тематичні панельні дискусії та прямі включення дали змогу простежити тренди світової контентіндустрії в умовах викликів пандемії.

Так, зокрема, експерти зазначили, що європейські медійні ринки, що відзначалися останнім часом потужним виробництвом контенту, 3 приходом пандемії COVID-19 також мали необхідність вносити корективи. Державні локдауни, зупинка роботи продакшенів, скасування зйомок окреслили перспективу потенційної нестачі контенту [1, с. 91].

«Комплексний аналіз медіаіндустрії Центральної та Західної Європи, а також Великої Британії спеціально для KYIV MEDIA WEEK Global Marathon підготували експерти британської аналітичної компанії Ampere Analysis і іiї голова Гай Біссон (Guy Bisson)» [1, с. 91]. Вони зауважили, що вплив коронавірусу на європейську індустрію контенту виявився лише в прискоренні змін, що вже відбувалися. Серед найвиразніших трендів, які засвідчили експерти, - «активне перетікання аудиторії з лінійного ТБ на стримінги, зростання популярності нонскріптед-сегмента і посилення копродукційних зв'язків» [1, с. 92]. Так. зокрема, фінансова аналітика змусила компанію Ampere Analysis переглянути свої очікування на наступні п'ять років у всіх нішах медіаіндустрії, і тільки щодо SVoD - у бік зростання. «У процентному вираженні найбільше постраждав прогноз щодо поширення контенту на фізичних носіях, а в грошах - очікування від ринку онлайн-реклами» [1, c. 92].

Відповідно, пандемія активізувала стримінг-сервіси, тож великі студії Центральної та Західної Свропи активно переформатовують роботу на користь потокового мовлення, адже, за словами експертів, в Європі зауважують посилення зацікавленості виробників контенту i мовників у сегменті нонскріптед. 


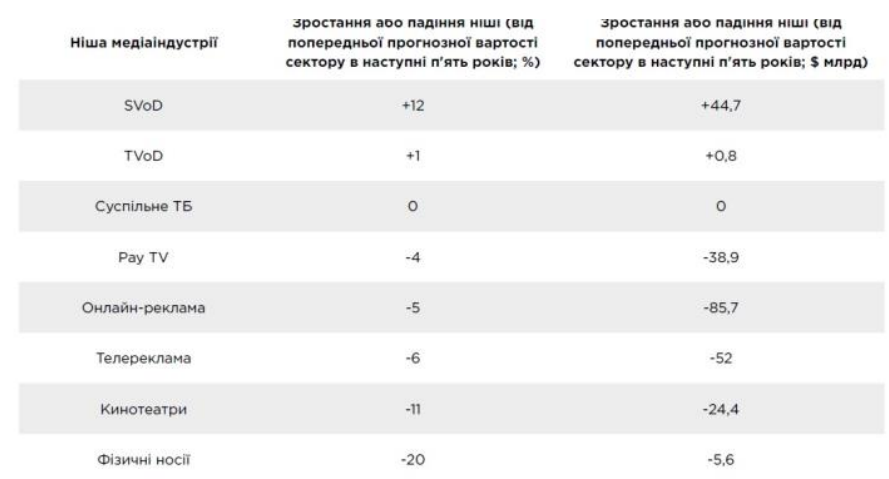

Рис. 1. Перегляд експертних прогнозів щодо різних ніш медіаіндустрії [1, с. 92]

Щодо жанрових тенденцій автори аналітичного огляду експертних думок європейських фахівців зауважують, що «у березні 2020 року випуск скріптед-контенту очікувано пішов на спад, а його місце в сітці зайняли більш легкі у виробництві й за змістом телешоу та документалістика. Якщо впродовж 2019-го європейські виробники випускали по кілька десятків ігрових проєктів на тиждень, то тепер кількість щотижневих прем'єр ледь дотягує до 10-15» [1, с. 93].

Серед запитів замовників-європейців у 2020 році сталися зрушення від жанрів реаліті, наукової фантастики та драматичних серіалів до розважальних проєктів, дитячого контенту і контенту глобального, де підіймаються поточні проблеми людства. Загалом, рейтинги очолюють проєкти екологічного, політичного та соціального, зокрема правозахисного (наприклад, у топі проблематика ЛГБТ) спрямування.

Національні європейські мовники прослідкували й вікову динаміку, на яку стримінги, як виявилося, не вплинули. «Експерти порівняли показники перших кварталів 2016 та 2020 років, і виявилося, що аудиторії 45-54 і 55-64 не тільки залишаються вірними лінійному ТБ, але й нарощують його дивлення. Молодь - 18-24 і 25-34 - передбачувано мігрує в бік стримінг-сервісів, а от глядачі середнього віку споживають контент усіма доступними способами. Завдяки цьому потокові сервіси за останні чотири роки суттєво наростили кількість передплатників (кількість переглядів збільшилася 3 18\% у першому кварталі 2016-го до 47\% в аналогічному періоді 2020-го) [1, с. 93]. Ці дані підтверджують великі компанії, зокрема Nordic Entertainment Group (NENT), до складу якої входить 30 продакшенів, а також запущена недавно онлайн-платформа Viaplay, (очікують до кінця 2020 року 600 тис. користувачів). Тут прогнозують тенденції до збільшення 
неангломовного контенту, що для скандинавських студій може означати новий етап популярності.

В аналітичному огляді засвідчено прогнози щодо популярних шоу європейських мовників, серед яких: легкі розважальні шоу (напр. Lodgers for Codgers (канал Channel 4) («своєрідний соціальний експеримент, де молодь і старше покоління намагаються звести разом (не в романтичному сенсі, а виключно в розумінні співжиття на умовах оренди): дуже позитивний формат, спрямований на задоволення потреби людей в об'єднанні» [1, с. 95]), Claudias House of Love (Banijay Group, Endemol Shine Germany) - реаліті-шоу в жанрі дейтинг, де селебриті шукає любов; Insonnia / Insomnia (Rai) - ток-шоу формату late night, в якому обговорюють культурні теми; The Chop: Britain's Top Woodworker (Sky) - шоу на тему ремонту зі змагальним елементом; Sweden Strongest Family (Jarowskij productions) - змагальне шоу, адаптація ірландського формату компанії Magnify Media Block [1, c. 97].

Міжнародний виробник контенту Banijay Group (базується у Франції) також підкреслюють популярність нонскріптед-контенту та комедійних форматів.

Медіаринок Німеччини, що у допандемічний час переважно адаптував контент інших країн, зорієнтований на вироблення оригінального контенту (напр., компанія NEUESUPER).

Тож, європейське виробництво у складні трансформаційні часи зорієнтовано на оригінальні проєкти, як ігрові, так і нонскріптед, як на лінійному ТБ, так і на онлайн-платформах, що відповідає трендам глобальної контент-індустрії 2020 року, окресленим К. Удут, директоркою Media Resources Managementвід, на основі даних експертів The Wit, виведених на основі аналізу нових форматів і шоу, які стали цього року реакцією виробників контенту зі всього світу на нові умови [1, с. 5]: «Ми можемо вижити» (We may survive): 1) «Ми можемо вижити 3 маскою» (у тому числі маються на увазі «замасковані» формати, напр., корейський The Masked Singer чи турецький Good Singer. 2) «Ми можемо вижити разом із форматами-довгожителями» («ставка» на перевірені часом проєкти; 3) «Ми можемо вижити і зрозуміти, хто ми є».

\section{Література:}

1. Новий світ - нові виклики. Аналітичний огляд онлайн-марафону: тренди й перспективи аудіовізуальної індустрії України та світу / За ред. А. Давидової. Київ : ТОВ «Інформаційне агентство «Медіа ресурси менеджмент», 2020. 154 с. 